УДК 65.02.34:629.73(043.3)

DOI: https://doi.org/10.37320/2415-3583/14.14

Харченко М.В.

кандидат економічних наук,

Кременчуцький льотний коледж

Харківського національного університету внутрішніх справ ORCID: https://orcid.org/0000-0001-7435-0642

Цимбалістова О.А.

кандидат економічних наук,

Кременчуиький льотний коледж

Харківського національного університету внутрішніх справ ORCID: https://orcid.org/0000-0001-8565-3710

Юденко Є.В.

кандидат економічних наук,

Кременчуцький льотний коледж

Харківського національного університету внутрішніх справ ORCID: https://orcid.org/0000-0002-5122-726X

\title{
ФОРМУВАННЯ ПОНЯТТЕВО-КАТЕГОРІЙНОГО АПАРАТУ ГЕОЛОГІСТИКИ В УМОВАХ ІНФОРМАЦІЙНОЇ ЕКОНОМІКИ
}

У статті висвітлюеться сутність та зміст поняття «геологістика». Окреслено передумови розвитку та иілі геологістики як складової частини глобальної (міжнародної) логістики в умовах інтеграції національної економіки Украӥни до європейського та міжнародного економічного простору. Систематизовано фундаментальні завдання геологістики з урахуванням ї̈ просторово-функиіональних властивостей $i$ зв'язків у наднаціональному вимірі. Сформовано перелік основних інфраструктурних елементів геологістики. Визначено місие та роль сучасних інформачійних технологій в управлінні логістичними потоками. Доведено, щсо ключовим напрямом розвитку інформаційних технологій в геологістиці є комплексна інтеграція інформаційних потоків та комунікаційне забезпечення логістичних потоків. Охарактеризовано прогресивні технологї, щзо використовуються для інформаційного забезпечення транскордонних логістичних потоків.

Ключові слова: логістика, геологістика, логістична концепція, транспортна геологістика, інформаційна система, транспорт, логістичний потік, транскордонні перевезення.

Постановка проблеми. В умовах глобалізації світової економіки та підвищення динамізму конкурентного бізнес-середовища все більшого значення набувають такі аспекти ведення бізнесу та обслуговування споживачів, як якість, своєчасність і точність задоволення їхніх запитів. У результаті зростає роль транспорту і логістики, а створення ефективно діючих транспортнологістичних систем стає актуальним завданням.

Значущим чинником інтеграції національної економіки України до європейського та міжнародного економічного простору є раціональна організація логістичних потоків. Складовою частиною оптимізації руху логістичних потоків у цьому контексті є геопросторова організація територіальних логістичних систем на основі концепції геологістики. Адже сучасна концепція геологістики в контексті геоекономічного підходу виступає основою формування геоекономічної стратегії розвитку національного господарства в умовах інформаційного суспільства.

Аналіз останніх досліджень і публікацій свідчить, що науково-методологічні та прикладні засади формування та функціонування геологістики, як наукового напряму у вітчизняній науковій парадигмі перебувають на етапі формування і потребують поглибленого вивчення.

Вагомий внесок у становлення та розвиток теоретико-методологічних засад геологістики та економічної географії здійснили зарубіжні й вітчизняні науковці, такі як П. Діккен, Дж.-П. Родріге, І. Смирнов, О. Топчієв, О. Шаблій та ін. Різноманітні аспекти геологістичних досліджень відображено у працях таких учених, як: Д. Ковен, В. Грицевич, В. Дергачов, О. Ільєнко, О. Катерна, О. Качур, Л. Литвиненко, М. Сеньків, I. Шум тощо.

3 погляду науковців О. Ільєнко та О. Катерни, геологістика - це інноваційний напрям у логістичній науці, котрий концентрується на формуванні й розподілі міжнародних транспортних потоків, а також відстеженні ix у реальному режимі часу на основі використання сучасних географічних інформаційних систем (ГІС) 3 метою знаходження оптимальних рішень, забезпечуючи об'єднання процесів функціональних структур підприємства в єдину систему [5].

В. Дергачов під геологістикою розуміє комплексний підхід до руху матеріальних цінностей на основі комплексного поєднання методів та засобів управління товарним потоком [4, с. 6] Отже, в межах цього підходу геологістика забезпечує ефективну територіальну організацію та управління транспортними та іншими економічними потоками.

М. Сеньків трактує поняття «геологістика» як новий науково-практичний напрям, що вивчає суспільно-географічні чинники та геопросторову організацію територіальних логістичних систем і створюваних ними пасажирських, вантажних, інформаційних і фінансових потоків [8, с. 54]. Відповідно М. Сеньків вказує, що геологістика формується на межі географії та логістики. У своїх дослідженнях науковець виокремлює сім головних напрямів дослідження геологістики: 
1) теоретичні та науково-практичні основи геологістики;

2) суспільно-географічні передумови логістичної діяльності;

3) процеси інтеграції України у європейську транспортно-логістичну систему;

4) геопросторові аспекти аграрної логістики;

5) геопросторові аспекти митної логістики;

6) геопросторові аспекти логістики туризму;

7) екологічні аспекти геологістики.

Вказаний підхід включає різні аспекти транспортної та розподільчої геологістики для певної території або напряму бізнесу, проте принципова різниця предмета вивчення геологістики від економічної географії полягає у вивченні не територіальних аспектів розміщення та руху виробничих ресурсів, а безпосередньо міжтериторіальних (регіональних, наднаціональних та міжконтинентальних) потокових процесів [8, с. 54-55].

У надбаннях В. Грицевича запропоноване тринітарне розуміння предмета дослідження суспільної географії як єдності трьох компонент: геосферної взаємозумовленості земних явищ, геопросторової мінливості суспільних явищ і геотериторіальної організованості суспільства. Проте в дослідженнях науковця превалює тенденцією щодо орієнтації на «геопросторову організацію» виробничих сил та ресурсів [3, с. 53-59].

Аналіз наукової літератури дає змогу констатувати, що геологістику можна охарактеризувати як логістику у наднаціональному, глобальному вимірі. Разом із тим геологістика потребує більш глибокого вивчення як бізнес-концепція ефективного застосування геоінформаційних систем у процесі планування, прогнозування та підтримки прийняття управлінських рішень у логістичній діяльності сучасних компаній.

Мета статті. Метою дослідження є вивчення та удосконалення поняттєво-категорійного апарату геологістики в умовах розвитку інформаційної економіки, уточнення сутності їі ключових понять.

Виклад основного матеріалу дослідження. Глобалізація світової економіки та інтенсивний розвиток інформаційних технологій потребує новітніх підходів до управління рухом наднаціональних (транскордонних) економічних і фінансових потоків в системі міжнародних зв'язків. Тенденція до глобалізації світової економіки, активізація та розширення міжнародного співробітництва, розвиток транспортних сполучень, системи інформаційного та комунікаційного забезпечення сприяють розвитку геологістики.

У цих умовах інтенсифікуються процеси активного залучення в міжнародну конкуренцію величезних і складних як національних, так і багатонаціональних структур, інститутів і організацій. Для того щоб отримати стійкі конкурентні переваги і домогтися максимальної вигоди та результативності за рахунок масштабів виробництва, доцільно використовувати національні, континентальні та регіональні переваги і можливості. Ефективний розвиток та взаємодія учасників світового економічного простору вимагають відповідного інструментарію та засобів керування, що дають змогу управляти складними процесами переміщення, розміщення, зберігання та розподілу матеріальних і нематеріальних активів 3 урахування факторів політичного, економічного, соціального, науково-технічного та екологічного характеру.
Отже, актуальність розвитку напряму геологістики в сучасних умовах визначається сучасними вимогами світового інтегрованого економічного і соціального розвитку.

Варто виокремити такі передумови розвитку геологістики як складової частини глобальної (міжнародної) логістики $[3,4,8]$ :

- по-перше, потенційні, ресурсні можливості глобальних, міжнародних виробничих систем, переміщення, зберігання і розподіл товарних потоків дають змогу більш ефективно вирішувати господарські проблеми з організації та управління логістичними процесами й отримувати більші переваги, ніж під час реалізації логістичних можливостей лише на національній або міжнаціональній основі;

- по-друге, створення стійких конкурентних переваг і отримання максимальної економії за рахунок масштабів виробництва і стандартизації збутових та логістичних процесів у світовому масштабі;

- по-третє, глобальна (міжнародна) логістична система, заснована на інтегральному поєднанні ресурсів та сучасних геоінформаційних технологій, здатна забезпечити ефективне перетворення і рух матеріальних i нематеріальних активів із розміщених у різних частинах світу джерел обмежених економічних ресурсів та сировини в міжнародний інтегрований і гармонізований виробничо-господарський комплекс, а звідти - через безліч розподільних каналів, мереж, ланцюгів і ланок постачання конкретним споживачам в усьому світі.

На розвиток геологістики впливає низка чинників, що включають:

- процеси інтеграції світового господарства та формування інтермодальної (міжгалузевої) системи, що використовує комбіновані перевезення;

- зростання значущості інфраструктурного забезпечення логістичної діяльності, впровадження концепції інтегрованої логістики та створення транспортнологістичних центрів і кластерів з метою підвищення ефективності економічної діяльності;

- перехід від багатогалузевої транспортної системи до єдиних логістичних ланцюгів і активне формування мережевих структур в системі логістичного комплексу;

- диференціювання та ускладнення територіальної інфраструктури структури логістичного комплексу, появу нових елементів (контейнерні термінали і порти, хаби, гевеї, логістичні центри);

- концентрування - концентрування міжнародних логістичних потоків, формування полімагістралей та транспортних коридорів, мультимодальних транспортних вузлів, що об'єднують різноманітні види транспорту для обслуговування потужних міжнародних вантажо- і пасажиропотоків.

Завдання геологістики - це ефективне функціонування інтегрованого, гармонізованого і координованого комплексу логістичних потоків (матеріально-речових, вантажних, кадрових, пасажирських, енергетичних, сервісних, інформаційних, фінансових та ін.), формування полімагістралей та транспортних коридорів, інтер- та мультимодальних транспортних вузлів, що об'єднують різні види транспорту для обслуговування потужних міжнародних вантажо- і пасажиропотоків.

За рахунок комплексу засобів і методів геологістики забезпечується геопросторове поєднання еле- 
ментів транспорту, серед яких: транспортні мережі, транспортні засоби, потоки, системи управління та сукупність просторових зв'язків між ними на базі сучасних інформаційних технологій.

Базуючись на визначених вище завданнях, слід виокремити такі цілі геологістики (рис. 1).

Фундаментальні цілі геологістики спрямовані на:

1) організацію, забезпечення та супровід транскордонних логістичних потоків:

- виконання міжнародних договорів, угод, зовнішньоторговельних контрактів тощо;

- виконання зовнішньоторговельних комерційних і некомерційних операцій, міжнародного обміну усіма видами економічних ресурсів, включаючи фінансові, інформаційні, інноваційні, інвестиційні, трудові та інтелектуальні, а також матеріальними і не матеріальними цінностями, включаючи наукові, технічні, інтелектуальні, творчі, культурні, соціальні та ін.;

-гармонійне та ефективне поєднання національних логістичних потоків держав із регіональними логістичними потоками партнерів зовнішньоторговельної діяльності, органічно включаючи їх у міжнародну логістичну систему;

- обмін ефективними результатами інноваційного розвитку, продуктами науково-технічного прогресу, досягненнями науки і техніки, інвестиціями в межах міжнародних угод, правил, умов і договорів;

2) оптимізацію ресурсних, часових, трудових, сервісних та фінансових витрат на постачання ресурсів та кінцевого продукту від виробника до споживача, а також на оперативне, комфортне транспортування пасажирів і туристів у міжнародному просторі.

На підставі вивчення та комплексного аналізу актуальних досліджень і наукових публікацій можна сформувати завдання геологістики, що включають:

- розвиток міжнародних концентраційних і розподільних логістичних центрів, терміналів, транспортних вузлів, кластерів, хабів, а також потенційний розвиток різних видів транспорту і типів транспортних засобів, їх оснащення, експлуатаційних параметрів і характеристик;

- розроблення стратегії i тактики створення i функціонування стійких макрологістичних систем, що пов'язують транснаціональні корпорації і бізнесструктури різних держав світу зі своїми національ- ними логістичними системами на основі спеціалізації і поділу праці, партнерства та кооперування у формі договорів, контрактів, угод, загальних планів, законодавчо підтримуваних на міждержавному рівні;

- проектування нових транспортних маршрутів i коридорів, ланцюгів поставок, уніфікованих і спеціальних транспортних засобів, вантажних одиниць, їх технологічного оснащення, концентраційних і розподільних логістичних центрів, перевантажувальних терміналів, ефективних комунікацій, вантажних одиниць, тари та упаковки;

- організацію ефективних логістичних потоків матеріальних ресурсів, пасажирів, інформації, фінансових і інтелектуальних ресурсів, інвестицій, сервісних послуг між країнами і континентами;

- розроблення та підтримку гармонізованих та інтегрованих ланцюгів постачання від виробника до одержувача (покупця/споживача);

-забезпечення та супровід міжнародного транспортного товароруху усіма видами сервісного обслуговування, включаючи інформаційне, кадрове, експедиторське, технічне, страхове та правове;

- формування ефективного управління потоками матеріальних i нематеріальних цінностей, вантажів i пасажирів, інформацією, фінансами, сервісними послугами, професійними кадрами, взаємодією $з$ партнерами в процесі транспортування;

- організацію інформаційного забезпечення міжнародних товаропотоків із використанням прогресивних інформаційно-навігаційних систем.

Рушійною силою прогресивного розвитку глобальної логістичної системи виступає потреба у високошвидкісних транспортних системах і логістичних технологіях щодо обслуговування вантажовідправників і вантажоодержувачів. Забезпечення високої ефективності функціонування безпосередньо залежить від структури і процесів самих організацій, використовуваного обладнання та виробничих активів, інфраструктура транспортних систем тощо.

До системи інфраструктурних елементів геологістики слід віднести такі складники, як:

- транспортна система, включаючи залізничний, автомобільний, морський, річковий, повітряний та трубопровідний види транспорту;

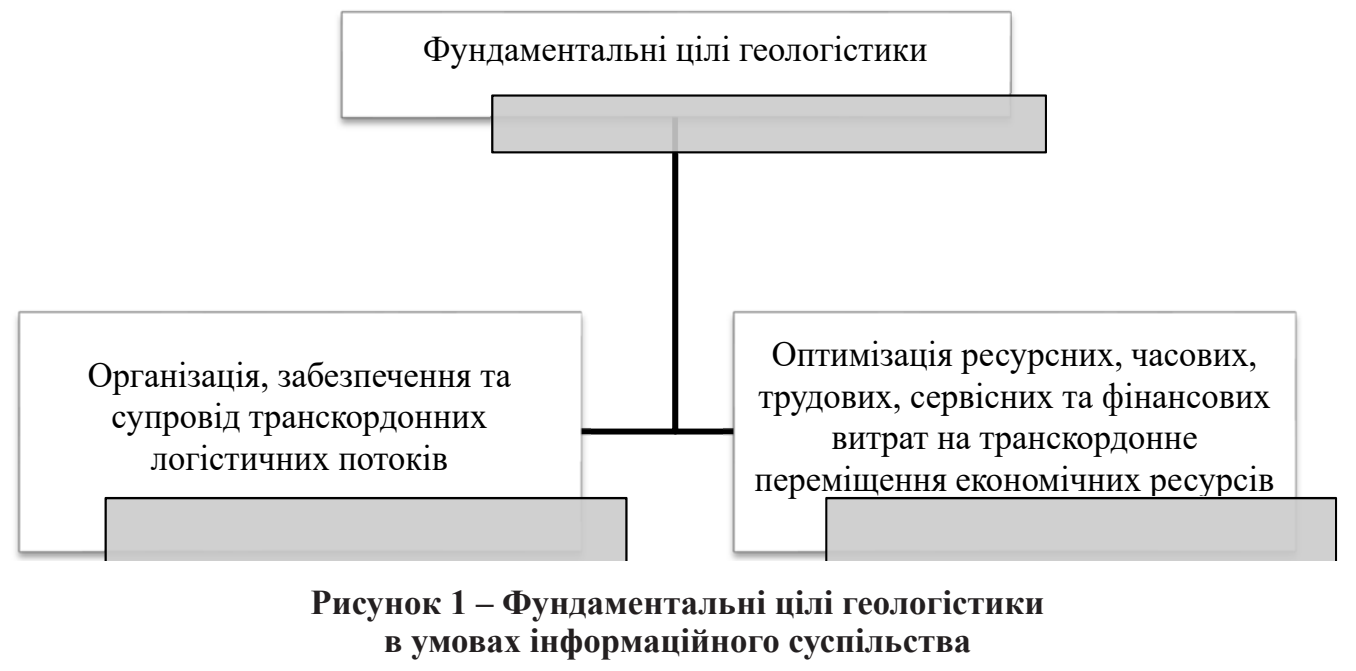


- транспортні вузли - прості та інтегральні (бімодальні, мультимодальні) - хаб (hub), гетвей або шлюз (gateway), термінал;

- система мультимодальних (змішаних/комбінованих) перевезень (склади тимчасового зберігання, міжнародні транспортні коридори);

- інформаційні технології та інформаційно-навігаційні системи;

- міжнародні логістичні центри, концентраційнорозподільні термінали і парки, майданчики і зони, регіональні кластери тощо.

Інтенсивний розвиток ринку транспортно-логістичних послуг створює об'єктивні організаційно-економічні передумови для формування транспортно-логістичних кластерів, які в умовах сьогодення $є$ найбільш ефективними інноваційно-орієнтованими формами інтеграції учасників ринку логістичних послуг. Взаємодія учасників ланцюга поставок на основі інновацій та узгодження економічних інтересів забезпечує максимальний синергетичний ефект.

Активний розвиток геологістики в Україні та світі тісно пов'язаний $з$ використанням сучасних інформаційно-навігаційних систем та технологій, які в свою чергу забезпечують умови ефективного використання транспортних систем задля оптимального планування перевезень, оперативного контролю місця розташування транспортних засобів та ефективного управління транспортними потоками.

Ключовим напрямом розвитку інформаційних технологій в геологістиці є інтеграція інформаційних потоків та комунікаційне забезпечення логістичних потоків. Адже в умовах динамічного розвитку економічних процесів ланцюги поставок набули глобального характеру, де всі учасники пов'язані воєдино на базі інформаційних систем, які координують кожен етап спільної діяльності, роботу логістичної інфраструктури та управління логістичними потоками.

3 метою забезпечення глобального моніторингу транснаціональних логістичних потоків, гнучкості та ризикостійкості ланцюгів постачання використовуються прогресивні IT-рішення - GPS-Traking, голосове управління (керування), RFID-мітки, автоматичні штабелери. 3 метою забезпечення самоор- ганізаційних відносин між клієнтами та постачальниками товарів і послуг відбувається формування мережі віртуальних транспортно-експедиторських агентств і посередницьких фірм в Internet, розвиток мережі швидкісних платних магістралей $з$ дистанційною формою розрахунків, розвиток глобального мобільного зв'язку «трубка - трубка», що забезпечується низькоорбітальними системами типу Globalstar, розвиток мобільного управління на основі WAP технологій, впровадження технологій «Green Custom» на основі EDI.

Використання сучасних геоінформаційних технологій в управлінні логістичними потоками дає змогу домогтися істотного скорочення витрат, оптимізувати терміни доставки, оптимально використовувати наявні ресурси і підвищити якість транспортування за рахунок просторового аналізу, моделювання, ведення єдиної географічної бази тощо.

Висновки. Отже, вивчення поняттєво-категорійного апарату геологістики в умовах інформаційної економіки дає змогу дійти висновку, що сучасна геологістика - це концепція управління товарними, вантажними (матеріальними), нематеріальними та пасажирськими потоками між державами і континентами в часі, просторі $з$ використанням інформаційних технологій та інформаційно-навігаційних систем. У результаті дослідження встановлено, що геологістика забезпечує прогнозування, планування і формування світових господарських зв'язків щодо постачання матеріальних ресурсів або надання сервісних послуг, їхній розвиток, раціоналізацію та оптимізацію. Геологістика забезпечує міжнародний рух товарно-матеріальних цінностей через вантажні термінали, місця складування, зберігання, концентрації і розподілу логістичних потоків (матеріального, інформаційного, фінансового, сервісного, інтелектуального, кадрового тощо).

Встановлено, що ключовим напрямом у системі розвитку логістичних центрів $є$ інтеграція інформаційних потоків і комунікаційне забезпечення транскордонного переміщення економічних ресурсів.

Перспективи подальших досліджень - вивчення закономірностей та архітектури геологістики в системі розвитку транспортно-логістичного бізнесу.

\section{Список використаних джерел:}

1. Воронов В.И., Воронов А.В. Международная логистика пространств и границ: основные аспекты формирования понятия, миссии, целей задач, функций, интегральной логики, принципов и методов. Управление. 2015. Т. 3 № 2. С. $27-36$.

2. Грицевич В.С. Тринітарний підхід до розуміння предмета дослідження суспільної географії. Науковий вісник Херсонського державного університету. Серія: географічні науки. 2019. Вип. 11. С. 25-30.

3. Грицевич В.С., Сеньків М.І. Поняттєво-термінологічні основи геологістики як актуального напрямку суспільної географiї. Економічна та соціальна географія. Київ, 2017. Вип. 78. С. 53-59

4. Дергачов В.А. Геополитический словарь-справочник. Киев : КНТ, 2009. 592 с.

5. Ільєнко О.В., Катерна О.К. Геологістика. Навчальний посібник. Київ : Видавництво «Кондор», 2016. 284 с.

6. Пашинська Н.М. Сучасні особливості територіальної організації транспортної системи. Проблеми суспільної географії: 3б. наук. пр. Київ : Інститут географії НАН України, 2010. Вип. 1. С. 36-40.

7. Печенюк А.В., Гуцол Т.Д. Сучасні інформаційні технології в транспортній логістиці. Вісник СНУ ім. Володимира Даля. 2010. № 6. C. 1-4.

8. Сеньків М.І. Логістика та геологістика в контексті суспільно-географічних досліджень. Географія, картографія, географічна освіта: історія, методологія, практика: матеріали міжнар. наук.-практ. конф. Чернівці : Вид. дім «Родовід», 2014. C. $185-186$.

9. Смирнов І.Г. Геологістика як напрям з територіально-екологічної оптимізації логістичних систем. Вісник Київського національного університету імені Тараса Шевченка. 2002. № 4. С. 47-53. 


\section{References:}

1. Voronov V.Y., Voronov A.V. (2015) Mezhdunarodnaia lohystyka prostranstv y hranyts: osnovnыe aspektы formyrovanyia poniatyia, myssyy, tselei zadach, funktsyi, yntehralnoi lohyky, pryntsypov y metodov [International logistics of spaces and borders: the main aspects of the formation of a concept, mission, goals of tasks, functions, integral logic, principles and methods]. Upravlenye, vol. 3 , no. 2 , pp. $27-36$.

2. Hrytsevych V.S. (2019) Trynitarnyi pidkhid do rozuminnia predmeta doslidzhennia suspilnoi heohrafii [Trinitarian approach to understanding the subject of research in human geography]. Naukovyi visnyk Khersonskoho derzhavnoho universytetu. Seriia: heohrafichni nauky, vol. 11, pp. 25-30.

3. Hrytsevych V.S., Senkiv M.I. (2017) Poniattievo-terminolohichni osnovy heolohistyky yak aktualnoho napriamku suspilnoi heohrafii [Conceptual and terminological basics of geologistics as an actual direction of human geography]. Ekonomichna ta sotsialna heohrafiia. Kyiv. Vol. 78, pp. 53-59

4. Derhachov V.A. (2009) Heopolytycheskyi slovar-spravochnyk [Geopolitical Dictionary- directory. Kyev: KNT. (in Russian)

5. Ilienko O.V., Katerna O.K. (2016) Heolohistyka [Geologistics]. Kyev: Vydavnytstvo «Kondor». (in Ukrainian)

6. Pashynska N.M. (2010) Suchasni osoblyvosti terytorialnoi orhanizatsii transportnoi systemy [Modern features of the territorial organization of the transport system]. Problemy suspilnoi heohrafii: Zb. nauk. pr. - Kyev: Instytut heohrafii NAN Ukrainy. Vol. 1, pp. $36-40$.

7. Pecheniuk A.V., Hutsol T.D. (2010) Suchasni informatsiini tekhnolohii v transportnii lohistytsi [Modern information technologies in transport logistics]. Visnyk SNU im. Volodymyra Dalia, no. 6, pp. 1-4.

8. Senkiv M.I. (2014) Lohistyka ta heolohistyka v konteksti suspilno-heohrafichnykh doslidzhen [Logistics and geologistics in the context of socio-geographical research]. Heohrafiia, kartohrafiia, heohrafichna osvita: istoriia, metodolohiia, praktyka: materialy mizhnar. nauk.-prakt. konf. Chernivtsi: Vol. dim «Rodovid», pp. 185-186.

9. Smyrnov I.H. (2002) Heolohistyka yak napriam z terytorialno-ekolohichnoi optymizatsii lohistychnykh system [Geolohistyka as a direction of territorial and ecological optimization of logistics systems]. Visnyk Kyivskoho natsionalnoho universytetu imeni Tarasa Shevchenka, no. 4. pp. 18-22.

\section{Kharchenko Maryna, Tsymbalistova Olena, Yudenko Evhen}

Kremenchuk Flight College of

Kharkiv National University of Internal Affairs

\section{FORMATION OF THE CONCEPTUAL AND CATEGORY APPARATUS OF GEOLOGISTICS IN THE CONDITIONS OF INFORMATION ECONOMY}

The urgency of geologistics studies in the conditions of transformation anddevelopment of economic systems is determined by the need of the national economic system to develop and strengthen the competitiveness of domestic business through the development of cross-border transportation, transit potential of Ukraine, enhancing international transport and logistics links. The purpose of the article is to study and improve the conceptual and categorical apparatus of geologistics in the context of the developing information economy, to clarify the essence of its key concepts. Both general and special scientific research methods were used in the article, namely theoretical generalization, analysis and synthesis, methods of functional-structural analysis, scientific abstraction. The article highlights the essence and content of the concept of \& quot; geologistics \& quot; as an effective geospatial organization of logistics flows (material, freight, personnel, passenger, energy, service, information, financial, etc.) between countries and continents. The preconditions of development and goals of geologistics in the globally integrated economic and social development are outlined. It is established that the fundamental goals of geologistics are aimed at organization, provision and support of cross-border logistics flows, optimization of resource, time, labor, service and financial costs for the supply of resources and the final product from a producer to a consumer, as well as for prompt, comfortable transportation of passengers and tourists across the globe. The list of factors of influence on formation and development of geologistics in the context of globally fundamental transformations and transformations of logistic concepts has been formed. The fundamental tasks of geologistics in the supranational dimension are systematized. The list of infrastructural elements of geologistics including transport system; transport nodes (bimodal, multimodal); the system of multimodal (mixed / combined) transportation; information technologies and information and navigation systems, international logistics centers, concentration and distribution terminals, parks, sites, zones, regional clusters, etc. has been formed. The place and role of modern information technologies in the management of logistics flows have been determined. The advanced technologies used for information support of cross - border logistics flows have been described.

Key words: logistics, geologistics, logistics concept, transport geologistics, information system, transport, logistics flow, international transportation. 